\title{
POLÍTICA E RELIGIÃO NO REGIME MILITAR: POSICIONAMENTOS DO LEGISLATIVO MUNICIPAL DE CAMPO MOURÃO/PR (1973-1982)
}

\section{POLITICS AND RELIGION IN THE MILITARY REGIME: POSITIONINGS OF MUNICIPAL LEGISLATIVE IN CAMPO MOURÃO/PR, BRASIL (1973-1982)}

\author{
Frank Antonio Mezzomo* \\ Lara Grigoletto Bonini**
}

\begin{abstract}
Resumo: O artigo se propõe a analisar as relações de imbricação e permeabilização entre os campos político e religioso, a partir da composição dos dois últimos mandatos do legislativo municipal de Campo Mourão, ocorridos durante o Governo Militar. Foram analisadas as atas e pronunciamentos dos vereadores, projetos de leis, além de homenagens e notas de destaque concedidas para agentes do campo religioso. Verificou-se que diversas instituições religiosas foram subsidiadas pela casa de leis, mediante concessão de recursos financeiros, doação de terrenos, declaração de utilidade pública, entre outros. Com base nas fontes e discussões teóricas é possível concluir que as manifestações religiosas não estão restritas apenas ao espaço privado e as articulações simbólicas são constitutivas das relações sociais.
\end{abstract}

Palavras-chave: Religião. Política municipal. Regime Militar.

\footnotetext{
* Professor no Programa de Pós-Graduação Sociedade e Desenvolvimento da Universidade Estadual do Paraná (UNESPAR), Campus de Campo Mourão.

E-mail: frankmezzomo@gmail.com

** Estudante no Curso de Graduação em História da Universidade Estadual do Paraná (UNESPAR), Campus de Campo Mourão. E-mail: larascs@hotmail.com
} 


\begin{abstract}
The article aimed to analyze the relations of imbrications and permeability between politics and religion, based on the last two compositions of legislature during Military Regime. It was analyzed records and pronouncements of city council representatives, bills, tributes and notes issued to agents of the religious field. It was found that several religious institutions were subsidized by the municipal legislative, by granting of financial resources, land donation, declaration of public utility, among others. Based on sources and theoretical discussions we conclude that the religious is not only restricted to the private sphere as well as symbolic articulations are constitutive of social relations.
\end{abstract}

Keywords: Religion. Municipal politics. Military Regime.

Ao tematizar a presença e a evocação dos discursos religiosos no âmbito do poder político, coloca-se em pauta uma problemática cara às Ciências Humanas, a saber, a imbricação e permeabilização dos campos político e religioso, enquanto compreensão teórica e constatação empírica, que ocorre à revelia de um movimento e defesa da secularização, defendido por muitos como inexorável e irreversível na contemporaneidade. ${ }^{1}$ A participação e a presença da religião na esfera pública, mesmo que incômoda na avaliação de alguns pesquisadores, podem ser evidenciadas na existência de símbolos, valores, rituais cristãos, homenagens, concessões de títulos, além das tradicionais benesses financeiras concedidas na forma de isenção de impostos e subvenções econômicas. Esses flagrantes históricos são problematizados, a seguir, na pesquisa desenvolvida, a qual buscou investigar a presença e invocação do campo religioso no legislativo municipal de Campo Mourão, ocorridas entre os anos de 1973 e 1982. O período compreende a composição dos dois últimos mandatos legislativos (1973-1976 e 1977-1982) formados durante o regime militar brasileiro (1964-1985).

O trabalho de campo foi realizado, sobretudo, no arquivo permanente ${ }^{2}$ da Câmara Municipal, em que se localizou vasta documentação: pauta de atas das sessões legislativas, projetos e anteprojetos de leis, proposições de decretos leis e ofícios, entre outros. Outra série de fontes utilizada são os boletins de urnas publicados pelo Tribunal Regional Eleitoral do Paraná, quando da realização dos pleitos eleitorais em 1972 e 1976. Nesses boletins são encontradas informações como o nome, o partido, a quantidade de votos e a condição de eleito ou de suplência de todos os candidatos concorrentes ao legislativo e executivo de Campo Mourão. ${ }^{3}$ Ao tratar esse corpus documental é possível identificar inúmeras passangens que flagram os constantes diálogos estabelecidos com os porta-vozes do campo religioso representado, nesse momento, por bispo, padres, pastores e presbíteros oriundos de instituições religiosas localizadas dentro e fora dos limites geográficos do município. 
A documentação utilizada, seja aquela pertencente ao arquivo permanente da Câmara Municipal ou a ela relacionada, possibilita que se problematizem as imbricações estabelecidas entre os porta-vozes do campo político e do campo religioso na década de 1970 e início de 1980, quando estiveram em vigência momentos distintos da vitalidade do regime militar. As fontes documentais podem ser compreendidas como indícios, pistas e sinais dessa época, além de terem sido produzidas por grupos humanos que (in)voluntária e (in)conscientemente expressam suas vontades e convicções político-sociais. Tomá-las na sua historicidade, isto é, como resultado de forças e disputas historicamente travadas, significa entendê-las na sua parcialidade e subjetividade. Cabe ao pesquisador, e aqui se recorre às reflexões de Carlo Ginzburg, adotar procedimentos interpretativos dos resíduos, sinais e pistas aparentemente marginais, pormenores às vezes imperceptíveis que podem permitir a compreensão das relações e formação cultural de um grupo social, de um período, de uma época. ${ }^{4}$

O material empírico coletado evidencia que as sessões da Câmara Municipal de Campo Mourão constituíam um dos momentos de maior exposição pública das demandas municipais, pois, para além da oficialidade burocrática do cotidiano da casa de leis, as sessões constituíam-se em palco e cenário adequados para celebração, e, por que não dizer, encenação pública do poder.

O texto, a seguir, está estruturado em quatro partes. Primeiramente procura-se compreender o alinhamento político de Campo Mourão, assim como a formação do bipartidarismo local inserido na conjuntura política estadual e nacional. Na sequência, em dois momentos, apresentam-se os indícios da presença do campo religioso nos discursos e práticas dos vereadores pertencentes às duas composições do legislativo, formadas entre os anos de 1973 a 1976 e 1977 a 1982. Por fim, à guisa de conclusão, procura-se apontar as imbricações e permeabilizações entre os campos político e religioso.

\section{O LEGISLATIVO MUNICIPAL E A CONFIGURAÇÃO POLÍTICA NACIONAL}

A organização política do estado brasileiro sofreu profundas mudanças no segundo quartel do século XX, por conta do golpe militar auspiciado pelas forçadas armadas brasileiras, em abril de 1964. Na vigência do regime militar foram adotadas medidas que, segundo os protagonistas do golpe, visavam efetivar a chamada revolução brasileira, garantindo o desenvolvimento e o progresso nacional. Durante os governos militares foram publicadas medidas, atos institucionais e decretos intervenientes no funcionamento dos sindicatos e entidades estudantis, na realização de greves, na liberdade de imprensa, além 
das conhecidas cassações de mandatos e suspensão de direitos políticos de parlamentares oposicionistas ao regime militar. ${ }^{5}$

A publicação dos 16 atos institucionais e complementares baixados pelos governos militares, entre 1964 e 1978, alterou de modo direto a conjuntura política nacional com reflexos imediatos nas composições político-partidárias locais. Nesse contexto pode-se mencionar o Ato Institucional $\mathrm{n}^{\mathrm{o}} 5$ (AI-5) que retirou o direito de escolher, pela via direta, o chefe supremo da nação, ou ainda o Ato Institucional $n^{\circ} 2$ (AI-2), publicado em outubro de 1965, quando o executivo federal extinguiu todos os partidos políticos brasileiros criando, a partir de então, dois novos organismos políticos, a Aliança Renovadora Nacional (ARENA) e o Movimento Democrático Brasileiro (MDB). Na compreensão de alguns pesquisadores, as duas siglas não continham o termo partido, pois estavam inseridas em uma compreensão de que se tratavam apenas de organizações provisórias, as quais, conforme os rumos eleitorais poderiam ser dissolvidas ou alteradas a qualquer momento. $\mathrm{O}$ fato é que os governos militares não inventaram suas próprias instituições político-representativas, como um partido mobilizador de massa. A reforma partidária introduzida pelo AI-2 de 1965 limitou-se a cancelar os registros das antigas agremiações, criadas após o período do Estado Novo, reorganizando as facções pró-regime e anti-regime nas siglas ARENA e MDB, respectivamente. ${ }^{6}$

AARENA e o MDB, ao longo dos 14 anos de vigência do bipartidarismo no Brasil, acumularam diferentes resultados nas urnas, seja nas eleições proporcionais - vereador, deputados estaduais e federais - como nas majoritárias - prefeito, governador e senador -, intercalando, em geral, melhor desempenho para o partido alinhado ao regime militar até início da década de 1970, e fortalecimento do MDB a partir das eleições de 1974. No Paraná essa dinâmica é recorrente nos 5 maiores municípios - Curitiba, Londrina, Maringá, Ponta Grossa e Cascavel - ressalvadas algumas particularidades no que tange a maior ou menor adensamento com a política militar $^{7}$ e, como se pode constatar à seguir, essa realidade não é estranha ao município de Campo Mourão.

A Câmara Municipal de Campo Mourão, ao longo das décadas de 1960 e 1970, manteve-se alinhada ao regime militar e cioso diante do convite enviado pelo governador do Paraná, Paulo Pimentel, em 1966, para que todos os vereadores mourãoenses se filiassem à organização política ARENA. ${ }^{8}$ Talvez por essa afinidade política e ideológica com as opções e rumos tomados pelo regime militar, as 11 vagas do legislativo municipal, nos pleitos de 1968 e de 1972, foram ocupadas exclusivamente por vereadores filiados à ARENA. Tal aproximação com as orientações do governo do estado, bem como do comando geral da nação presidida pelos militares, se repetiria nas eleições para o executivo municipal elegendo exclusivamente prefeitos filiados na ARENA. ${ }^{9}$

Consta nos arquivos da Câmara de Vereadores notas de solidariedade, concessão de honrarias municipais e moções de entusiasmo e apoio às 
autoridades militares, como por exemplo, a saudação efusiva a Ernesto Geisel, em 1974, por ocasião de sua posse como presidente do Brasil. Na primeira sessão após a posse do presidente da República, o vereador Jorge Garcia Árias discursa reiterando que "o Brasil recebe um novo impulso com a posse do general Ernesto Geisel na Presidência da República. Será uma nova etapa para o progresso do país". ${ }^{10}$ Cabe reiterar que o discurso do vereador mourãoense está em sintonia com os discursos militares que estandardizavam os anos do chamado milagre econômico, evidenciados pelos altos índices de crescimento da economia brasileira. Quando o general-presidente toma posse, o clima de euforia dos anos do "milagre" persistia. A ênfase no discurso do apogeu da economia brasileira se dava por uma decisão baseada em avaliações tanto econômica quanto política, mostrando a forte crença nos círculos dirigentes de que o Brasil era um país predestinado a crescer. ${ }^{11}$

Ainda no que tange à posse de Ernesto Geisel na presidência da República, o vereador Sérgio Sebastião Miguel relata um encontro dos correligionários da ARENA, ocorrido em Curitiba, capital do estado do Paraná, no qual estava presente o presidente da República. O vereador, na sessão legislativa municipal, apresentou alguns assuntos debatidos na referida reunião, como a formação do movimento da ARENA Jovem e sua organização na microrregião cuja sede seria em Campo Mourão. ${ }^{12} \mathrm{O}$ vínculo e engajamento dos vereadores ao partido considerado do governo também podem ser assinalados a partir do requerimento do vereador Zamir José Teixeira, que solicita, conforme orientações do governador do estado do Paraná e do presidente da República, que sejam divulgadas "todas as coisas boas que foram feitas pela Arena, como exemplo, o pedido de iluminação, o asfalto e etc." nos jornais e rádios da comunidade. ${ }^{13}$ Essa nota pode, apropriadamente, ser compreendida consoante a uma política desenvolvida pelo governo militar voltada à construção e reinvenção otimista da realidade social, tendo contado, para tanto, com recursos financeiros e suporte tecnológico para a produção de filmes, documentários e propagandas enaltecendo o feito e desempenho alcançado durante o regime militar. ${ }^{14}$

Convêm destacar que, em meio às preocupações específicas do contexto regional, ressoam na Câmara Municipal dos Vereadores as composições e dilemas políticos e econômicos do final da década de 1970. Em Campo Mourão, desde a vigência do bipartidarismo, somente no pleito eleitoral de 1976 o MDB consegue ocupar três das onze vagas na casa legislativa municipal. Nesta perspectiva, o pesquisador José Carlos Alcântara, ao analisar as composições partidárias no município de Maringá/PR nesse período, entende que o MDB deixa de ser um partido temeroso e consegue apoio do eleitorado e também de dissidentes da ARENA. A adesão e o crescimento do MDB na esfera nacional é, em grande parte, reflexo da desilusão e esvaziamento do milagre econômico, além do aumento do coro daqueles que passam a questionar o regime militar e 
o mito da nação grande e pujante. Aos poucos, no entendimento de Alcântara, o MDB passa a ser acreditado como um partido de oposição. ${ }^{15}$ Em outubro de 1978, por meio da Emenda Constitucional $n^{\circ} 11$, o pluripartidarismo é reinstalado embora com fraca definição ideológica. ${ }^{16}$ As atas do legislativo de Campo Mourão flagram este momento de impasse político, como na última sessão ordinária do ano de 1979 quando o vereador Eudes Sartor expressa que "a extinção dos partidos veio dar igualdade a todos os políticos militantes", posição semelhante do vereador João Sérgio Kffuri que declara que será possível "trabalhar politicamente de uma forma mais democrática e mais independente". Por fim, o vereador José Luiz Gurgel justifica que "as lutas encetadas pelo MDB deverão indelevelmente marcar na memória de todos os brasileiros". ${ }^{17}$

\section{COMPOSIÇÃO E DESENVOLVIMENTO DO LEGISLATIVO MUNICIPAL NO SÉTIMO MANDATO (1973 A 1976)}

O processo eleitoral para composição do sétimo mandato para o executivo e legislativo municipal de Campo Mourão foi realizado em 15 de novembro de 1972. São eleitos 11 vereadores para um mandato que se estende até $1976 .{ }^{18}$ Todos os vereadores eleitos, conforme destacado acima, são filiados à ARENA, o que mostra a hegemonia e alinhamento do poder local com as orientações oriundas de Brasília.

A posse dos eleitos ao executivo e legislativo municipal ocorreu em 31 de janeiro de 1973. A solenidade iniciou com o hasteamento das bandeiras no Paço Municipal, seguida de uma missa solene em Ação de Graças, presidida pelo bispo Dom Eliseu Simões Mendes na catedral São José. Horácio Amaral, que então deixava o mandato de prefeito, em seu pronunciamento, agradeceu pela colaboração prestada à sua administração, em especial ao bispo Dom Eliseu Simões Mendes, às igrejas evangélicas representadas pelos pastores, ao deputado estadual Armando Queiroz de Moraes, à Câmara de Vereadores, além dos funcionários e operários municipais. Do mesmo modo, o prefeito que assumia o poder executivo, Renato Fernandes Silva, invocou a proteção dos céus para o mandato que se iniciava. ${ }^{19}$

No exercício do mandato dos vereadores que compuseram a sétima legislatura é possível destacar aproximações com o campo religioso. Trata-se de moções e anteprojetos de leis concedendo doações de terrenos, isenção de taxas de serviços públicos, concessão de homenagens, notas de destaque, entre outros. Conforme se constata, embora tenha ocorrido maior trânsito com representantes da igreja católica, outras entidades religiosas, sendo ou não cristãs, contaram com as benesses do poder púbico, todas, de alguma forma, causando manifestação dos edis vereadores. 
A religião católica, certamente, apresenta maior presença e diálogo com o legislativo como pode ser conferido em alguns exemplos, conforme segue. A vereadora Maria Enilda de Oliveira solicita que a Câmara ratifique o pedido para que o executivo estude a viabilidade financeira para construção de um monumento em homenagem a Santa Cruz, a ser construído no bairro homônimo. Após justificativas apresentadas pela autora, o pedido foi aprovado por unanimidade. ${ }^{20} \mathrm{Na}$ mesma sessão legislativa, o vereador Zamir José Teixeira informa que no dia 03 de dezembro o bispo Dom Eliseu completa 25 anos de bispado, quando será realizada uma missa festiva com a comunidade e presença de padres e bispos de outras dioceses. ${ }^{21}$ Endossando a nota de destaque apresentada, o vereador Aldo Jose Kaul solicita que a Câmara envie um ofício ao bispo felicitando pela ocasião. ${ }^{22}$

Outro requerimento que envolve a simbologia católico-cristã é registrado na ata de 17 de maio de 1976. Trata-se da solicitação da vereadora Maria Enilda de Oliveira, para que o executivo realize melhorias na iluminação pública da praça do bairro Jardim Lar Paraná, onde está localizada a paróquia Nossa Senhora do Caravággio. A vereadora justifica a proposição, haja vista que a comunidade está se preparando para as festividades decorrentes da recepção da imagem de Nossa Senhora Aparecida, vinda de Aparecida, São Paulo. ${ }^{23} \mathrm{Na}$ sessão do dia 21 de junho de 1976, após a data comemorativa da paróquia do bairro Jardim Lar Paraná, o vereador Zamir José Teixeira agradece o empenho e colaboração de Feiz Farhat, responsável pelo Departamento de Serviços Urbanos, que teria providenciado melhorias nas vias públicas preparando Campo Mourão para acolhida da padroeira do Brasil. ${ }^{24}$

Em relação à concessão de benfeitorias, pode-se destacar o ofício protocolado pelo vereador Francisco Irineu Brezinski, em 20 de agosto de 1973, solicitando ao executivo a doação para a Catedral de Campo Mourão de um relógio semelhante ao modelo existente na Catedral de Curitiba. Na sessão de 22 de outubro do mesmo ano, a pedido do vereador Delordes Daleffe, requereuse o restabelecimento de mais lâmpadas nas laterais da Catedral Diocesana. As proposições foram aprovadas por unanimidade.

Ainda, sobre as benesses às instituições religiosas, localizou-se o anteprojeto de Lei n. 09/76, de 22 de março de 1976, que declara a igreja evangélica Assembleia de Deus como de Utilidade Pública, significando que, por ser entidade sem fins lucrativos e cujas ações são reconhecidas como complementares à ação do Estado, podem ser financiadas e tuteladas por ele. ${ }^{25}$ Nessa mesma condição está a Missão Luterana Livre que, pelo Projeto de Lei n. 28/74, os vereadores reconheceram como sendo de Utilidade Pública, além de auxílios financeiros destinados para incrementar atividades esportivas organizadas pela mesma igreja. ${ }^{26}$

A Câmara de Vereadores autorizou, mediante o anteprojeto de Lei n. 15/75 de junho de 1975, o executivo municipal a fazer doação de terreno para a 
Sociedade Beneficente Muçulmana de Londrina e Norte do Paraná. O vereador José Costa Maria justifica que tal doação será utilizada para construção da Mesquita e a Escola Árabe no município. O jornal Folha de Londrina registrou a visita do Sheik Ahmad Saleh El Mohairi, representante do governo da Arábia Saudita a Campo Mourão, sendo recebido pelo prefeito Renato Fernandes e pelo presidente da Câmara, vereador Francisco Irineu Brzezinski, no início do mês de novembro de 1975. ${ }^{27}$ Segundo relata o historiador Jair Elias, a cerimônia teria ocorrido entre os dias 31 de outubro e 1 de novembro de 1975, quando oficialmente foi doado um terreno de 620 metros quadrados situado na Avenida Guilherme de Paula Xavier. ${ }^{28}$

Demais instituições religiosas foram beneficiadas com doações de terrenos, como a igreja Congregação Cristã no Brasil, por meio do anteprojeto de Lei n. 32, de 18 de outubro de 1976, autorizando a doação de terreno para a edificação de uma igreja. Na mesma sessão legislativa, o anteprojeto n. 37 estabelece doação de terreno a Mitra Diocesana de Campo Mourão, para a construção de uma capela na localidade denominada de Km 123. Detalhe digno de nota é de que no anteprojeto segue uma justificativa assinada pelo bispo Dom Eliseu. ${ }^{29}$

Outro aspecto que envolve o fazer dos vereadores e a oficialidade da Câmara são as celebrações e festejos cívico-religiosos, estes últimos vinculados sobretudo à Igreja católica. A festa nacional de Corpus Christi é ilustrativa para explicitar a relação de cumplicidade entre os poderes público e religioso. A ata legislativa de 18 de junho de 1973 registra o convite do prefeito municipal, Renato Fernandes Silva, para que os vereadores participem da procissão festiva católica. O prefeito ainda reitera que, ao compartilharem da celebração de Corpus Christi, os vereadores "darão um testemunho a Deus e comunidade, de humanismo e cristandade". ${ }^{30}$ A partir da fala do prefeito ao convidar os vereadores é possível considerar a importância de participar e dar este testemunho público de adesão ao ritual católico em que, por meio da manifestação pública, a "Igreja deseja manter seus laços com a comunidade, pressuposto básico de toda procissão e reafirmar a importância da celebração de sua existência". ${ }^{31}$

A sessão de 10 de outubro de 1973 é solene porque representa a data de emancipação político-administrativa de Campo Mourão. No plenário da Câmara, além dos representantes do legislativo, também participam autoridades que receberiam homenagens dos poderes municipais. Entre os homenageados consta o bispo Dom Eliseu que, em nome de todos, discursa dizendo que "se fizemos algo por esta cidade, pelo bem dos outros, foi com o maior espírito cristão". Na mesma sessão solene, o bispo ainda enaltece o município, explicando "quando fui nomeado para cá, não sabia onde ficava esta cidade, porque nem em mapas constava, e hoje, Campo Mourão já está projetado no cenário nacional". Por fim o bispo arremata dizendo "agora não podemos parar, 
vamos todos continuar a trabalhar em ritmo de Brasil Grande". ${ }^{32}$ É possível perceber que a menção do bispo traz, de forma explícita e aberta, a aproximação e o alinhamento com os discursos oficiais, próprios do regime militar, quando enalteciam o que seria um marco constitutivo de um "Brasil grande", "Brasil potência", comandado pelos legítimos representantes do povo, os militares. ${ }^{33}$ O bispo Dom Eliseu participa da entrega do título de cidadão honorário ao ex-vereador Fioravante João Ferri. ${ }^{34}$

É importante anotar que nem todas as proposições dos vereadores envolvendo o campo religioso são aceitas e aprovadas por unanimidade. Um exemplo interessante por evidenciar, talvez, a pouca articulação política e afinidade com as convicções religiosas, esteve envolvido na solicitação apresentada pelo vereador Sergio Sebastião Miguel, em maio de 1973. O pedido pleiteava a doação de um terreno do bairro Jardim Country Club à entidade maçônica Luz do Oriente. Junto ao requerimento seguia um ofício da Loja Maçônica informando sobre metas de assistência social e desenvolvimento de obras filantrópicas como albergue noturno e a extensão do pronto-socorro, ambos destinadas à assistência de pessoas pobres e desempregadas. A solicitação causou divergências entre os vereadores que decidiram deixar a decisão para o executivo municipal. ${ }^{35}$

\section{COMPOSIÇÃO E DESENVOLVIMENTO DO LEGISLATIVO MUNICIPAL NO OITAVO MANDATO (1977 A 1982)}

A nova eleição do município de Campo Mourão é realizada em 15 de novembro de 1976, na qual são eleitos 8 vereadores da ARENA e 3 vereadores do MDB. ${ }^{36}$ A posse dos representantes da oitava composição do legislativo ocorreu em 01 de fevereiro de 1977 em sessão solene da Câmara Municipal. Entre as autoridades estiveram presentes os presidentes dos diretórios regionais da ARENAe do MDB, que também fizeram uso da palavra durante a solenidade. Ao final da sessão, o presidente da mesa, vereador Ephigênio José Carneiro, faz os tradicionais agradecimentos, não se esquecendo de reverenciar a figura divina. Também desta composição, a incidência dos diálogos entre o campo político e religioso continuam intensos.

Os agentes políticos municipais denotam aproximações com o campo religioso pedindo inspiração e iluminação divina para o exercício do mandato ${ }^{37}$, além das frequentes distinções por ocasião dos festejos religiosos constantes no calendário cívico nacional. Entre os exemplos pode-se mencionar o destaque do vereador José Luiz Gurgel ao mencionar que, conforme calendário católico, dia 18 de outubro é comemorado o "Dia de São Lucas". Já a vereadora Amélia Almeida Hruschka e o vereador Ephigênio, em alternadas sessões legislativas, pronunciam-se sobre a comemoração do "Dia de Ação de Graças". ${ }^{38}$ A 
supracitada vereadora também se manifesta na casa legislativa homenageando o "Dia da padroeira do Brasil, a nossa Senhora Aparecida". ${ }^{39}$

Ephigênio José Carneiro, dentre os demais eleitos para o legislativo, é possivelmente o vereador que cria mais demandas junto ao campo religioso. Consta entre suas reivindicações, a solicitação de homenagens a autoridades religiosas, concessão ou mesmo endosso nos pedidos de apoio financeiro e isenção de impostos a templos, além da invocação, em seus discursos, do arcabouço retórico oriundo do campo mágico-religioso. Nesse sentido, vale destacar a proposição do vereador ao solicitar que, na abertura dos trabalhos do legislativo, se fizesse uma saudação a Deus, afinal, e aqui a justificativa é curiosa, a Câmara de Vereadores "é uma casa constituída por cristãos, que creem e vivem na doutrina de Cristo". ${ }^{40}$

Dentro desse mesmo entendimento destaca-se, conforme lembrança do supracitado vereador, em companhia do também vereador Manoel Pereira Martins, a deferência concedida à bíblia, já que o mês de setembro, para os católicos, é dedicado em sua homenagem. Assim, além da leitura de trechos bíblicos ao final das sessões, durante o mês comemorativo a bíblia deveria ficar exposta no plenário da Câmara Municipal. Conforme atas das sessões da Câmara, a menção à bíblia aparece em vários anos. ${ }^{41} \mathrm{~A}$ presença e as constantes referências a símbolos e rituais religiosos em espaços públicos, como alguns teóricos já mencionaram, parecem sinalizar para a não realização e concretização da separação entre a esfera religiosa e a esfera política, confirmando, em grande medida, a existência de certa permeabilização mútua entre o mundo sagrado e o mundo profano. ${ }^{42}$

A Campanha da Fraternidade, iniciativa eminentemente católica, é citada na sessão de 28 de março de 1978 pelo vereador Ephigênio José Carneiro que, em tema livre, discorre sobre o tema da campanha "Trabalho e justiça para todos". Na mesma sessão, o vereador Eudes Sartor, do MDB, na esteira das homenagens e menções à campanha, faz seu pronunciamento chamando a atenção para a política partidária. $\mathrm{O}$ referido vereador discorre que "justiça e trabalho para todos é o que nós também desejamos", e explica que pretensos líderes atacam a oposição, atrapalham e tumultuam o trabalho do MDB no município. A manifestação teria provocado alguns incômodos entre os vereadores que, após a suspensão da sessão por alguns minutos, retornaram aos trabalhos legislativos. ${ }^{43}$ Vale retomar, conforme apontado acima, que a partir de meados da década de 1970 assiste-se no âmbito nacional e estadual à fragilização do regime militar refletida, inclusive, em sucessivas perdas eleitorais da ARENA, base de apoio do governo militar. Em Campo Mourão, tal situação não é diferente, de modo que após sucessivas gestões hegemônicas da ARENA, tanto no executivo como legislativo municipal, viu-se o partido do governo perder força eleitoral, mesmo com a introdução do pluripartidarismo, em dezembro de $1979 .{ }^{44}$ 
Na sessão realizada em 29 de março de 1978, possivelmente no contexto do mal estar ocorrido entre os vereadores na sessão anterior, o vereador arenista Ephigênio discursa em plenário pedindo paz e harmonia entre os edis legisladores municipais. No clima das comemorações da Semana Santa, findada na semana anterior, o vereador recorre ao significado do festejo religioso e a trechos extraídos da bíblia, a fim de persuadir os componentes da Câmara Municipal para a missão da vereança em proceder conforme os exemplos deixados por Cristo, isto é, procurar servir e não ser servido. Ao fim da sessão, o vereador teria apresentado algumas passagens bíblicas como indicativo de reflexão semanal para os demais colegas de mandato. ${ }^{45}$

Na mesma toada reflexiva de inspiração católica, o vereador Ephigênio, com base em um artigo publicado em revista católica, homenageia o "Dia das Mães" associando o papel materno às figuras de Maria e Cristo. ${ }^{46} \mathrm{O}$ supracitado vereador utiliza ainda o jornal L'Osservatore Romano para homenagear o Papa Paulo VI (1963-1978), falecido em 6 de agosto de 1978. Após discorrer sobre a biografia do pontífice Paulo VI, reitera que o momento é de escolha do novo papa, sendo declarada, em 26 de agosto do mesmo ano, a eleição de Albino Luciani, o Papa João Paulo I. ${ }^{47}$ A posse do novo papa, assim como sua repentina morte e a escolha de Karol Wojtyla, nomeado como Papa João Paulo II (1920-2005), são noticiadas e registradas nos anais da Câmara de Vereadores de Campo Mourão. ${ }^{48}$

Convém ressaltar que as aproximações entre a Câmara de Vereadores e a religião também ficam evidenciadas nos mais variados tipos de apoios e benefícios concedidos às instituições eclesiásticas. Entre as deliberações do legislativo, ressaltam-se os projetos de lei que reconhecem algumas entidades religiosas como de Utilidade Pública, como a Igreja Adventista do Sétimo Dia e a Loja Maçônica Oliveira Zanini, em 1978 e 1979, respectivamente, por iniciativa dos vereadores João Sérgio Kffuri e José Pedroso Fabri. Em 1982, com projetos propostos pelos vereadores Amélia Hruschka e José Luiz Gurgel, foram ainda contempladas com tal benefício a Loja Maçônica Associação das Acácias Luz do Oriente, a $1^{\text {a }}$ Igreja Presbiteriana Renovada de Campo Mourão e a Associação Evangélica Missão Transmundial.

Há ainda as entidades religiosas beneficiadas por meio de doações de terrenos a partir de requerimentos e projetos de lei do poder executivo e legislativo. Entre eles pode-se citar a solicitação do vereador Eudes Sartor, na sessão de 18 de outubro de 1978, pedindo a doação de terreno à Igreja Seicho-no-iê do Brasil, núcleo de Campo Mourão. Doa-se também um terreno à Igreja Evangélica Pentecostal "O Brasil para Cristo", conforme consta no Projeto de Lei n. 63/82, para a construção de um templo religioso. Outra entidade beneficiada é a igreja evangélica Assembleia de Deus, ratificada por meio do Projeto de Lei n. 09/81 transformada na Lei Municipal n. 299/81. No projeto, apresenta-se a necessidade de construção de um templo religioso 
para o atendimento dos adeptos no bairro periférico da cidade. Novamente, a igreja evangélica Assembleia de Deus é favorecida, por meio de projeto de lei do poder executivo. Entre as justificativas para a doação consta o apoio à entidade que promove o bem e propaga os ensinamentos de Deus em uma sociedade rodeada pela violência e injustiça. ${ }^{49}$

Todavia, a proposição do vereador José Luiz Gurgel, em 20 de junho de 1979, solicitando a isenção de impostos, taxas e asfaltamento das entidades religiosas do município provocou divergências entre os vereadores, possivelmente pelo impacto financeiro que tal medida causaria aos cofres públicos. $\mathrm{O}$ autor da proposição justifica o requerimento por entender que as entidades religiosas, que não aferem lucros em suas atividades e lutam em prol do bem da humanidade, deveriam ser isentas de recolhimento de tributos municipais. O projeto foi aprovado com o voto minerva do presidente da Câmara, o que demonstra o impasse encontrado pelo legislativo municipal. A polêmica, que teria extrapolado o ambiente da sessão ordinária, mereceria uma nova manifestação do vereador, quando retomaria o tema ressaltando as dificuldades financeiras pelas quais passam as entidades religiosas. ${ }^{50}$

\section{APONTAMENTOS CONCLUSIVOS}

A segunda metade do século XX foi marcada por uma grande reviravolta no campo religioso, uma vez que o famigerado vislumbrar do novo milênio, com suas ameaças catastróficas, a mudança da era de peixes para a era de aquário, conforme a astrologia, os conflitos político-ideológicos intercontinentais travados pelos blocos norte-americano e soviético e o fluxo da contracultura dos anos de 1960, delineavam um momento de insegurança, que se fazia sentir inclusive no campo epistemológico, ao decretar o fim das verdades estáveis e legitimidade dos paradigmas calcados na racionalidade moderna. ${ }^{51}$ O campo religioso brasileiro, especificamente, não passaria incólume, com mudança substantivas introduzidas, sobretudo, pelo crescimento das religiões neopentecostais e encolhimento quantitativo da Igreja Católica. Tais mudanças provocaram alterações e redefinições no próprio fazer das agências do sagrado.

O certo, na compreensão de Joanildo Burity, é que não se pode mais ignorar a visibilidade pública das religiões. Quer no plano da cultura e do cotidiano, quer no da esfera pública e da política, os agentes religiosos movimentam-se e trazem a público sua linguagem, seu ethos e suas demandas nas mais diversas direções..$^{52}$ Não significa, entende Regina Novaes, fundir os dois campos, mas reconhecer tais especializações, historicamente construídas na modernidade, sem reificar a oposição entre o político como lugar da razão e da ordem pública, e o religioso enquanto espaço do simbólico e da ordem da vida privada. Trata-se, antes, de apreender os efeitos da religião sobre a 
política e vice-versa, afinal, deixar de considerar analiticamente a presença da "religião na política é colocar para debaixo do tapete variáveis constitutivas de processos políticos em curso" ${ }^{33}$ Com isso, não se trata de discutir se há ou deve haver uma aproximação entre religião e política, mas sim entender que o vínculo está historicamente construído e se expressa na massiva imbricação entre religião e cultura. ${ }^{54}$

A análise não somente das religiosidades como das instituições religiosas perpassa historicamente a esfera pública e contribui para a conservação da ordem social. Como aponta o sociólogo francês Pierre Bourdieu, o campo religioso também cumpre uma função externa de legitimação da ordem estabelecida na medida em que a manutenção da ordem simbólica contribui diretamente para a manutenção da ordem política. ${ }^{55}$ Assim, ainda que a sociedade seja proclamada como laica, a conotação religiosa evidencia-se em caracteres públicos e políticos, mantendo-se e fazendo-se presente em todo o conjunto social.

A permeabilização entre as fronteiras do político e do religioso é verificada na experiência histórica da Câmara de Vereadores de Campo Mourão nos dois últimos mandatos do regime militar, relativos aos anos de 1973/1976 e 1977/1982. Em diversas oportunidades as instituições religiosas foram subsidiadas pela casa legislativa, ainda que determinadas proposições em favor de algumas entidades acarretassem discordâncias ou debates entre os vereadores. As instituições foram beneficiadas com auxílios do poder executivo e legislativo, mediante a transferência de recursos financeiros, doação de terrenos para construção de igrejas e templos, concessão de crédito a entidades assistenciais, declaração de Utilidade Pública, entre outros. Um argumento recorrente justificando tais deliberações é a contribuição dessas entidades para a sociedade.

É válido apontar, mesmo que rapidamente, a existência de vasta literatura que vem discutindo as articulações entre iniciativas de ação social de agentes governamentais, igrejas e a sociedade civil. É notório que alguns serviços públicos são executados em parcerias com agentes do campo religioso, por vezes, mais ágeis, ciosos e eficientes que a burocracia estatal. Tal aproximação, uma vez mais, acaba aproximando dois campos de semântica e base jurídica distantes, cujo movimento é, ao que parece, tensionado tanto pela política quanto pelo religioso. Quanto a esse, o religioso, pode-se dizer que parte dessas ações surge como estratégia de inserção pública das religiões, embaladas numa perspectiva proseletista de ampliar o rebanho de fiéis, e parte ancorada em uma nova cosmologia em que o discurso da caridade implica uma postura moral ativa e de mudança social surgida, marcadamente, na década de $1970 .{ }^{56}$ Conforme Burity, tais mudanças do campo religioso brasileiro inserem um duplo marco interpretativo: maior presença pública das religiões e o ambíguo processo da valorização da cultura como recurso crucial do desenvolvimento 
social, abrindo neste contexto espaço à religião como força social favorável à inclusão e à construção de identidades cidadãs. $\mathrm{O}$ campo das políticas públicas, notadamente as da área social, tem se tornado, nesse sentido, um espaço ilustrativo das aproximações e tensões implicadas numa redefinição em curso do marco republicano nas relações entre estado e religiões. ${ }^{57}$

A imbricação político-religiosa é flagrada ainda com a presença de agentes religiosos que participam do modus operandi do legislativo, bem como de diversas datas comemorativas do município. Entre estas ocasiões destacam-se a concessão de homenagens e notas de destaques aos porta-vozes do sagrado, além da presença em diversas sessões solenes e comemorativas promovidas pelo legislativo. Nessas oportunidades, os pronunciamentos dos líderes eclesiásticos - como o do bispo diocesano - reiteram a posição da Igreja de endosso à política municipal e cumplicidade com o regime militar nacional.

Ainda é possível constatar a presença de representantes do legislativo e do executivo municipal em celebrações religiosas, o que aponta para aquilo que Rosendahl e Gil Filho ${ }^{58}$ chamam a atenção acerca do prestígio e posição social do campo religioso, especificamente o católico, nas atuações públicas. A concelebração religiosa, além de ato exclusivamente espiritual envolvendo leigos e autoridades, são sacralizados na casa de leis com aprovação de projetos afinados com as demandas religiosas, assim como reverência às datas e símbolos sagrados, todos, ao seu modo, denotando um relacionamento cordial dos vereadores com o campo da religião.

Aqui vale a reflexão para além da racionalidade simplista ancorada na afirmação do 'toma lá dá cá', baseada em uma lógica fria e calculista. Os apoios mútuos entre os campos religioso e político estão envolvidos em trocas simbólicas e construção de sentido. A linguagem religiosa, expressada também em signos e metáforas bíblicas, quando embrenhada nas relações socioculturais, é capaz de atribuir legitimidade e sacralizar a política. ${ }^{59}$ Assim, a aproximação e convivência entre os porta-vozes do sagrado e da política, podem transmitir uma mensagem de cumplicidade e sintonia político-social. Essa situação parece recorrente na Câmara Municipal de Campo Mourão, conforme evidenciado no corpus documental cotejado.

Por fim, pode-se afirmar com base no material empírico analisado e as discussões teóricas apresentadas, que a presença do campo religioso nas demandas do legislativo municipal foram intensas durante os mandatos constituídos em 1973 e 1977, no tocante à aprovação de benefícios financeiros e a concessões de títulos e homenagens públicas. Tal inferência permite afirmar que as manifestações religiosas não estão reduzidas ao espaço privado e nem mesmo restritas a dinâmicas simbólicas espirituais, senão que sua presença está articulada na constituição cultural e na tessitura das relações sociais. 


\section{NOTAS}

${ }^{1}$ Cf. MONTERO, Paula. Secularização e espaço público: a reinvenção do pluralismo religioso no Brasil. Revista Etnográfica, v. 13, n. 1. Lisboa, maio 2009, p. 7-16; GIUMBELLI, Emerson. A presença do religioso no espaço público: modalidades no Brasil. Revista Religião e Sociedade, Rio de Janeiro, v. 28, n. 2, p. 80-101, 2008.

2 BELLOTTO, Heloísa et al. A ordenação interna dos fundos. In: .Arquivos permanentes: tratamento documental. São Paulo: T. A. Queiroz, 1991.

${ }^{3}$ Os boletins de urna são produzidos e disponibilizados pelo Tribunal Regional Eleitoral do Paraná, estando disponíveis em: <http://www.tre-pr.jus.br/eleicoes/resultados/resultados-deeleicoes-municipais-tre-pr>.

${ }^{4}$ GINZBURG, Carlo. Sinais: raízes de um paradigma indiciário. In: . Mitos, emblemas, sinais: morfologia e história. São Paulo: Cia. das Letras, 1989.

5 Cf. FICO, Carlos. "Prezada Censura": cartas ao regime militar. Revista Topoi, Rio de Janeiro, dez. 2002, p. 251-286; AQUINO, Maria Aparecida de. Censura, imprensa, estado autoritário (1968-1978). Bauru: Edusc, 1999; HABERT, Nadine. A década de 70: apogeu e crise da ditadura militar brasileira. São Paulo: Ática, 1992.

${ }^{6}$ CODATO, Adriano Nervo. Uma história política da transição brasileira: da ditadura militar à democracia. Revista Sociologia e Política, Curitiba, n. 25, nov. 2005, p. 98; CARVALHO JÚNIOR, Moacir Ribeiro de. A votação do MDB no Paraná: uma análise histórica (1966 e 1978). In: CODATO, Adriano Nervo; SANTOS, Fernando José dos (Orgs.). Partidos e eleições no Paraná: uma abordagem histórica. Curitiba: Tribunal Regional Eleitoral do Paraná (TREPR), 2006.

${ }^{7}$ O pesquisador José Eduardo Mosquera considera que "Do regime militar [...] surgiram a subserviente Aliança Renovadora Nacional, a Arena, e, como oposição consentida, o Movimento Democrático Brasileiro, o MDB". Sobre a Aliança Renovadora Nacional, Mosquera sintetiza: "fundada em 4 de abril de 1966, a Arena operou como braço político do Exército, o partido que realmente mandava, até ser liquidada em 29 de dezembro de 1979, quando o regime decidiu e o Congresso Nacional decretou o fim do bipartidarismo e o restabelecimento de um sistema multipartidário". Cf. MOSQUERA, Jorge Eduardo França. A votação da ARENA no Paraná: uma análise histórica (1966 e 1978) In: CODATO, Adriano Nervo; SANTOS, Fernando José dos (Orgs.). Partidos e eleições no Paraná: uma abordagem histórica. Curitiba: Tribunal Regional Eleitoral do Paraná (TRE-PR), 2006, p. 103.

8 Ata da Sessão Ordinária Legislativa em 06 de junho de 1966. Arquivo da Câmara Municipal.

9 Trata-se dos prefeitos Horácio Amaral (01/02/69 a 31/01/73), Renato Fernandes Silva (01/02/73 a 31/01/77) e Augustinho Vecchi (01/02/77 a 31/01/83).

${ }^{10}$ Ata da Sessão Ordinária Legislativa em 18 de março de 1974. Arquivo da Câmara Municipal de Campo Mourão.

${ }^{11}$ Cf. GASPARI, Élio. A ditadura escancarada: as ilusões armadas. São Paulo: Companhia das Letras, 2002; LOWY, Michel. A guerra dos deuses: religião e política na América Latina. Petrópolis: Vozes, 2000; FAUSTO, Boris. História concisa do Brasil. 2 ed. São Paulo: Edusp, 2009.

${ }^{12}$ Ata da Sessão Ordinária Legislativa em 18 de novembro de 1975. Arquivo da Câmara Municipal de Campo Mourão. 
${ }^{13}$ Ata da Sessão Ordinária Legislativa em 01 de dezembro de 1975. Arquivo da Câmara Municipal de Campo Mourão.

${ }^{14}$ FICO, Carlos. Reinventando o otimismo: ditadura, propaganda e imaginação social no Brasil. Rio de Janeiro: Fundação Getúlio Vargas, 1997. p. 41.

${ }^{15}$ ALCÂNTARA, José Carlos. O bipartidarismo (1966-1978) e a volta do pluripartidarismo em Maringá. In: DIAS, Reginaldo Benedito; GONÇALVES, José Henrique (Orgs.). Maringá e o norte do Paraná: estudos de história regional. Maringá: Eduem, 1999.

${ }^{16}$ MOSQUERA, Jorge Eduardo França. A votação da ARENA no Paraná: uma análise histórica (1966 e 1978) In: CODATO, Adriano Nervo; SANTOS, Fernando José dos (Orgs.). Partidos e eleições no Paraná: uma abordagem histórica. Curitiba: Tribunal Regional Eleitoral do Paraná (TRE-PR), 2006.

${ }^{17}$ Ata da Sessão Ordinária Legislativa em 22 de novembro de 1979. Arquivo da Câmara Municipal de Campo Mourão.

${ }^{18}$ A eleição para a composição da sétima legislatura é realizada em 15 de novembro de 1972. São mais de 13 mil eleitores que elegem 11 vereadores da Aliança Renovadora Nacional. Os vereadores eleitos foram: Maria Enilda de Oliveira (1.456 votos); Francisco Irineu Brzezinski (1.337 votos); Zamir José Teixeira (1.319 votos); Delordes Daleffe ( 930 votos); José Boiko (760 votos); Jorge Elizardo Garcia Arias (704 votos); José Costa Maria (699 votos); Antonio Maluf (678 votos); Sergio Sebastião Miguel (642 votos); Aldo José Kaul (613 votos); e Olimpio Batista de Araújo (493 votos). Cf. TRIBUNAL REGIONAL ELEITORAL DO PARANÁ. Disponível em: $<$ http://www.tre-pr.jus.br/eleicoes/resultados/resultados-de-eleicoes-municipais-tre-pr $>$. Acesso em: 07 jul. 2013.

${ }^{19}$ SANTOS JÚNIOR, Jair Elias. A história da câmara municipal de Campo Mourão: 19631976. Campo Mourão: Kromoset, v. II, 2006.

${ }^{20} \mathrm{O}$ requerimento da vereadora Maria Enilda de Oliveira, que foi aprovado por unanimidade, solicita a "construção de um monumento no marco histórico de Campo Mourão, representado pela Santa Cruz, no Jardim Santa Cruz, deste município". A vereadora esclarece sobre "a edificação do citado monumento que é um marco histórico de Campo Mourão, representado pela Santa Cruz. Conta-se que há muito tempo uma pessoa acidentou-se e prometeu caso se restabelecesse, que plantaria uma cruz nos limites da cidade. No início era um lugar de fé, eu quando criança, muitas vezes o frequentei. Faziam-se naquele local encontros de fé, e contam inclusive milagres. Sendo a cruz símbolo do Cristianismo, sugeria que no local fosse colocado o referido monumento. Solicitou a palavra o vereador Zamir José Teixeira e disse: na verdade, é oportuna a sugestão da nobre vereadora, nós que também somos pioneiros, e que por muitas vezes visitamos aquele local, sentimos o sentimento cristão do povo. Parabéns, pois essa indicação nos enche de satisfação". Ata da Sessão Ordinária Legislativa em 02 de dezembro de 1975. Arquivo da Câmara Municipal de Campo Mourão.

${ }_{21}$ "Com a palavra o vereador Zamir José Teixeira diz: na verdade, no dia de amanhã, o bispo de Campo Mourão, D. Eliseu Simões Mendes, completará 25 anos de bispado, sendo que 15 em nosso município. Tenho conhecimento que já se encontram em nossa cidade grande número de bispos de outras dioceses, que estarão celebrando uma missa no dia de amanhã. Sob seu comando, estão várias paróquias e casas paroquiais, ele foi um dos idealizadores e fundadores de nossa Faculdade, e inclusive já recebeu o título de cidadania honorária de nosso município e vários votos de louvor". Ata da Sessão Ordinária Legislativa em 02 de dezembro de 1975. Arquivo da Câmara Municipal de Campo Mourão.

${ }^{22}$ Ata da Sessão Ordinária Legislativa em 04 de dezembro de 1975. Arquivo da Câmara Municipal de Campo Mourão. 
${ }^{23}$ Ata da Sessão Ordinária Legislativa em 17 de maio de 1976. Arquivo da Câmara Municipal de Campo Mourão.

${ }^{24}$ Ata da Sessão Ordinária Legislativa em 21 de junho de 1976. Arquivo da Câmara Municipal de Campo Mourão.

${ }^{25}$ BASTOS, Vânia Lúcia Baltar. Declaração de utilidade pública. Disponível em: <http:// www.almg.gov.br/bancoconhecimento/tecnico/UtiPub.pdf>. Acesso em: 21 jul. 2013.

${ }^{26}$ Trata-se dos requerimentos apresentados pelos vereadores Aldo José Kaul (sessão de 25 de março de 1976) e Amélia de Almeida Khuschka (sessão de 23 de março de 1977). Os requerimentos foram aprovados por unanimidade.

${ }^{27}$ FOLHA DE LONDRINA. Campo Mourão terá mesquita e escola árabe-brasileira. Londrina, 06 nov. 1975, p. 06.

${ }^{28}$ SANTOS JÚNIOR, op. cit., p. 166.

${ }^{29}$ O Anteprojeto de Lei que autoriza doação de terreno a Mitra Diocesana de Campo Mourão possui um anexo encaminhado a Câmara Municipal com mensagem assinada pelo bispo diocesano Eliseu Simões Mendes: "Agradecendo antecipadamente por mais este gesto de colaboração, aproveito o ensejo para reiterar minha estima e consideração." Anteprojeto de Lei n. 37/76. Lei n. 136 de 03 de novembro de 1976. Arquivo da Câmara Municipal de Campo Mourão.

${ }^{30}$ Consoante ao discurso do prefeito municipal, Renato Fernandes Silva, o vereador Francisco Irineu Brzezinski ratifica: "queremos agradecer o convite do sr. prefeito para a festividade religiosa, em que comungaremos com todo o espírito cristão". Ata da Sessão Ordinária Legislativa em 18 de junho de 1973. Arquivo da Câmara Municipal de Campo Mourão.

${ }^{31}$ ANDRADE, Solange Ramos de. Espaço sagrado e sacralização do espaço: aspectos da procissão de Corpus Christi em Maringá-PR. Revista Brasileira de História das Religiões, Maringá, ano IV, n. 11, setembro 2011. Disponível em: $<$ http://<www.dhi.uem.br/gtreligiao/ artigo.html>. Acesso em: 26 abr. 2013.

${ }^{32}$ Ata da Sessão Solene Legislativa em 10 de outubro de 1973. Arquivo da Câmara Municipal de Campo Mourão.

${ }^{33}$ MENEZES, Fernando Dominience. Enunciados sobre o futuro: ditadura militar, Transamazônica e a construção do "Brasil grande". Dissertação (Mestrado em História), UNB, Brasília, 2007. p. 147.

${ }^{34} \mathrm{O}$ bispo Dom Eliseu homenageia o ex-vereador Fioravante João Ferri, dizendo ser necessário lembrar "dos exemplos desses que aqui vieram e venceram, Fioravante João Ferri, que teve a coragem de vir, ver e vencer, embora não sendo um dos pioneiros, foi um dos desbravadores da região". Ata da Sessão Solene Legislativa em 10 de outubro de 1974. Arquivo da Câmara Municipal de Campo Mourão.

${ }^{35}$ Entre as posições contrárias a doação do terreno consta a posição da vereadora Maria Enilda de Oliveira em que menciona estar "o patrimônio público... recebendo pedidos de interesse comercial sendo necessário um estudo e uma racionalização das doações". Ata da Sessão Ordinária Legislativa de 21 de maio de 1973. Arquivo da Câmara Municipal de Campo Mourão.

${ }^{36}$ A oitava legislatura municipal de Campo Mourão, cujo mandato se estendeu entre os anos de 1977 e 1982, foi ocupada por 11 vereadores, sendo 8 pela ARENA e 3 pelo MDB. Vale ressaltar que o vereador da ARENA que ocupou a última vaga ao legislativo recebeu mais votos que o vereador mais votado do MDB, o que evidencia, ainda, uma predominância do partido situacionista ao regime militar. Entre os representantes da ARENA foram eleitos: 
Amelia Almeida Hruscka (2.509 votos); Aroldo Gonçalves Neto (1.011 votos); José Costa Maria (975 votos); Joaquim Messias da Silva (887 votos); Ephigênio José Carneiro (804 votos); João Teodoro Oliveira Sobrinho (794 votos); Manoel Pereira Martins (673 votos) e João Sergio Kffuri (666 votos). Pelo MDB foram eleitos os seguintes vereadores: Eudes Sartor (643 votos); José Luiz Gurgel (530 votos) e José Pedroso Fabri (372 votos). Cf. TRIBUNAL REGIONAL ELEITORAL DO PARANÁ. Disponível em: $<$ http://www.tre-pr.jus.br/eleicoes/ resultados/resultados-de-eleicoes-municipais-tre-pr>. Acesso em: 07 jun. 2013.

${ }^{37} \mathrm{O}$ vereador Eudes Sartor registra um agradecimento a Deus, nos seguintes termos: "a Deus por permitir mais esta oportunidade de estarmos juntos para deliberar as causas e os problemas do nosso município". Ata da Sessão Ordinária Legislativa em 20 de agosto de 1979. Arquivo da Câmara Municipal de Campo Mourão.

${ }^{38}$ Ata da Sessão Ordinária Legislativa em 24 de novembro de 1977. Ata da Sessão Ordinária Legislativa em 23 de novembro de 1978. Arquivo da Câmara Municipal de Campo Mourão.

${ }^{39}$ Ata da Sessão Ordinária Legislativa em 16 de outubro de 1978. Arquivo da Câmara Municipal de Campo Mourão.

${ }^{40}$ Ata da Sessão Ordinária Legislativa em 18 de maio de 1977. Arquivo da Câmara Municipal de Campo Mourão.

${ }^{41}$ As referências à comemoração do mês dedicado a bíblia consta nas seguintes atas: Ata da Sessão Ordinária Legislativa em 25 de setembro de 1977; Ata da Sessão Ordinária Legislativa em 20 de setembro de 1978; Ata da Sessão Ordinária Legislativa em 17 de setembro de 1979. Arquivo da Câmara Municipal de Campo Mourão. Embora tenha ocorrido em período anterior ao recorte temporal dessa pesquisa, cabe salientar a cerimônia de Entronização do Crucifixo, realizada em 1961, com a presença de autoridades políticas e eclesiásticas, com destaque para a participação do bispo Dom Eliseu Mendes. Cf. Ata da Sessão Solene Especial de Entronização em 23 de abril de 1961. Arquivo da Câmara Municipal de Campo Mourão.

${ }^{42}$ Cf. ELIADE, Mircea. O sagrado e o profano. São Paulo: Martins Fontes, 1992; e JÚNIOR RANQUETAT, Cesar Alberto. A presença do crucifixo nos tribunais brasileiros: laicidade e símbolos religiosos em discussão. Debates do Ner, Porto Alegre, ano 12, n. 20, jul./dez. 2011.

${ }^{43}$ Ata da Sessão Ordinária Legislativa em 28 de março de 1978. Arquivo da Câmara Municipal de Campo Mourão.

${ }^{44}$ Como exemplo, pode-se mencionar o fracasso eleitoral do partido situacionista nas eleições realizada em 15 de novembro de 1982. Para um mandato que se estenderia de 1983 a 1988, o PMDB ocupou 8 das 11 cadeiras da Câmara Municipal de Vereadores, além de eleger o prefeito municipal. O PDS, sucessor imediato da ARENA, ocupou as outras 3 vagas no legislativo de Campo Mourão. Cf. Câmara Municipal dos Vereadores de Campo Mourão: Nona legislatura. Disponível em: $<$ http://<www.cmcm.pr.gov.br/v6/intranet/arquivos/9legis.pdf $>$. Acesso em: 15 jul. 2013.

${ }^{45}$ Ata da Sessão Ordinária Legislativa em 29 de março de 1978. Arquivo da Câmara Municipal de Campo Mourão.

${ }^{46} \mathrm{O}$ vereador Ephigênio José Carneiro traz a casa de leis um artigo da revista católica "A família Cristã". No trecho lido pelo vereador, cita sobre "Cristo que fez-se homem por meio de uma mulher, quis ter uma mãe para nela encontrar afeto, carinho" e, fala ainda, sobre o aborto, pedindo para que os vereadores reflitam sobre a quantidade de abortos realizados no Brasil. Ata da Sessão Ordinária Legislativa em 23 de maio de 1978. Arquivo da Câmara Municipal de Campo Mourão. 
${ }^{47} \mathrm{O}$ vereador Ephigênio declara que "Agora, preparam-se os cardeais para a eleição do novo Papa, que substituirá Paulo VI, e nós como cristãos que somos com homens pertencentes a doutrina de Cristo, devemos nos unir a Deus e ao Espírito Santo, que inspire esses cardeais para que encontrem o nome certo". Ata da Sessão Ordinária Legislativa em 21 de agosto de 1978. Arquivo da Câmara Municipal de Campo Mourão.

${ }^{48}$ Identificou-se na documentação do legislativo o projeto de lei que concede a João Paulo II, o título de cidadão honorário de Campo Mourão. O projeto foi apresentado na reunião ordinária realizada em 17 de março de 1980. Ao que consta o projeto foi aprovado, embora não foi localizado o ato oficial da concessão do referido título ao representante eclesiástico. Cf. Ata da Sessão Ordinária Legislativa em 17 de março de 1980. Arquivo da Câmara Municipal de Campo Mourão.

${ }^{49}$ Consta em anexo ao anteprojeto de lei a mensagem do prefeito municipal, Augustinho Vecchi, justificando tal doação: "nobres vereadores, apesar de tanta violência, ainda existem pessoas voltadas para o bem, pregando a paz, através dos ensinamentos de Cristo, levando sua mensagem aos irmãos sedentos e com fome da palavra de Deus. Gente assim necessita de nosso apoio e de nossa colaboração, para que o desiderato proposto alcance os reais objetivos, no sentido de formar, pela pregação do Evangelho, a comunidade. Com esta justificativa, submetemos o incluso anteprojeto de lei, para que a Igreja Evangélica Assembleia de Deus, possa em local mais adequado e central, realizar seu trabalho evangélico". Lei n. 346 de 20 de agosto de 1982. Arquivo da Câmara Municipal de Campo Mourão.

${ }^{50}$ Colocado em votação o requerimento foi aprovado com o voto de minerva do presidente. Ao final, o vereador José Luiz Gurgel agradece "aos vereadores, João Teodoro de Oliveira Sobrinho, Manoel Pereira Martins, Eudes Sartor, José Pedroso Fabri e em especial ao senhor presidente, que deu voto de minerva, pela primeira vez usada durante nossa legislatura". Ata da Sessão Ordinária Legislativa em 20 de junho de 1979. Arquivo da Câmara Municipal de Campo Mourão. Cabe esclarecer que, em outra sessão legislativa, o vereador José Luiz Gurgel se manifesta novamente: "Tanta coisa foi dita em torno da isenção de impostos, taxas e asfaltamento às Igrejas de Campo Mourão. [...] O requerimento tem a finalidade de isentar as Igrejas, porque temos sentido o problema das Igrejas de Campo Mourão, eu particularmente pertenço a Igreja Católica e tenho ouvido dominicalmente, apelo no sentido de que os fiéis compareçam de maneira mais efetiva à coleta, para que possamos manter a nossa Igreja iluminada e limpa, pois ela tem dificuldade para assim proceder". Ata da Sessão Ordinária Legislativa em 21 de agosto de 1979. Arquivo da Câmara Municipal de Campo Mourão.

${ }^{51}$ MEZZOMO, Frank Antonio. Nós e os outros: proselitismo e intolerância religiosa nas igrejas neopentecostais. Revista de História e Estudos Culturais, Uberlândia, v. 4, ano V, n. 1, p. 2, jan./mar., 2008.

52 BURITY, Joanildo. Religião, política e cultura. Revista Tempo Social, São Paulo, v. 20, n. 2, p. 84, 2008.

${ }^{53}$ NOVAES, Regina Reyes. A divina política. Notas sobre as relações delicadas entre religião e política. Revista USP, São Paulo, n. 49, mar./maio 2001, p. 61-62.

${ }^{54}$ BURITY, Joanildo. Religião e política na fronteira: desinstitucionalização e deslocamento numa relação historicamente polêmica. Revista de Estudos de Religião, São Paulo, n. 4, 2001. p. 29-30.

${ }^{55}$ BOURDIEU, Pierre. A economia das trocas simbólicas. São Paulo: Perspectiva, 2007. p. 69.

${ }^{56}$ Discussões acerca participação pública das religiões no Brasil, consultar: LANDIM, Leilah (Org.). Ações em sociedade. Militância, caridade, assistência etc. Rio de Janeiro: Nau, 1998; 
MACHADO, Maria das Dores. Política e Religião: a participação dos evangélicos nas eleições. Rio de Janeiro: FGV, 2006; SILVA, Claudia Neves da. Igreja católica, assistência social e caridade: aproximações e divergências. Revista Sociologias, Porto Alegre, ano 8, n. 15, p. 326-351, jan./jun., 2006.

${ }^{57}$ BURITY, Joanildo. Organizações religiosas e ações sociais: entre as políticas públicas e a sociedade civil. Revista Anthropológicas, Recife, ano 11, v. 8, n. 2, p. 10, 2007.

${ }^{58}$ Conferir, respectivamente, ROSENDAHL, Zeny. Espaço e religião: uma abordagem geográfica. $2^{\mathrm{a}}$ ed. Rio de Janeiro: UERJ, 1996; e GIL FILHO, Sylvio Fausto. Estruturas da territorialidade católica no Brasil. Revista Electrónica de Geografía y Ciencias Sociales, Barcelona, v. X, n. 205, enero de 2006.

${ }^{59}$ Cf. SANCHIS, Pierre. Igreja e questão agrária: um posfácio. In: PAIVA, Vanilda (Org.). Igreja e questão agrária. São Paulo: Loyola, 1985; LENHARO, Alcir. A sacralização da política. 2 ed., São Paulo: Papirus, 1986.

Artigo recebido em fevereiro de 2013. Aceito em julho de 2013. 